\title{
Michał Owczarek
}

Uniwersytet Łódzki

iD https://orcid.org/0000-0001-8198-677X

\section{Wizyta generała Wojciecha Jaruzelskiego w Watykanie w 1987 roku}

\section{Summary}

\section{General Wojciech Jaruzelski's visit to Vatican in 1987}

This article takes with the issue of General Wojciech Jaruzelski's visit to the Vatican, which took place at the beginning of 1987. It is a part of the results of the author's research on the re-establishment of diplomatic relations between Poland and the Holy See in 1989. The issue of normalization of relations between Warsaw and the Holy See in the 1980s, had not yet been taken up in the scientific discourse. The source basis are materials found by the author as a result of a query in the Archive of the Ministry of Foreign Affairs in Warsaw and the Archive of New Files in Warsaw. Additionally, notes from interviews and meetings published by priest Alojzy Orszulik used. Moreover, audiovisual materials in the form of the Polish Film Chronicle (PKF) were used.

The aim of the article is to present the preparations for the visit of General Jaruzelski to the Vatican, to reconstruct the atmosphere and relations between the state and the Catholic Church as well as Poland and the Holy See at that time and, finally, to present the course and the result of this visit. The article presents various views and summaries from both sides: Polish People's Republic and the Holy See. At the end, the answer to the question is why General Wojciech Jaruzelski's visit to the Vatican has become a breakthrough.

Keywords: diplomatic relations, Polish People's Republic, Holy See, Vatican City, John Paul II, Wojciech Jaruzelski, Agostino Casaroli, Achille Silvestrini.

\section{Streszczenie}

Artykuł podejmuje kwestię wizyty gen. Wojciecha Jaruzelskiego w Watykanie, która odbyła się na początku 1987 r. Jest to fragment wyniku badań prowadzonych przez autora na temat ponownego nawiązania stosunków dyplomatycznych między Polską a Stolicą Apostolską w 1989 r. Problematyka normalizacji stosunków zachodzących na linii Warszawa-Watykan w latach osiemdziesiątych XX w. nie była dotąd podejmowana w dyskursie naukowym. Podstawę źródłową stanowią materiały znalezione w wyniku kwerendy w Archiwum Ministerstwa Spraw Zagranicznych w Warszawie oraz Archiwum Akt Nowych 
w Warszawie. Uzupełnieniem są notatki z rozmów i spotkań opublikowane przez ks. Alojzego Orszulika. Ponadto wykorzystano materiały audiowizualne w postaci Polskiej Kroniki Filmowej.

Celem artykułu jest ukazanie przygotowań do wizyty gen. Jaruzelskiego w Watykanie, odtworzenie panującej ówcześnie atmosfery i relacji między państwem a Kościołem oraz Polską a Stolicą Apostolską, wreszcie zaprezentowanie przebiegu i skutków wizyty, które za sobą pociągnęła. W artykule ukazano różne spojrzenia i podsumowania zarówno ze strony PRL, jak i Kurii Rzymskiej. Na końcu znajduje się odpowiedź na pytanie, dlaczego wizyta przewodniczącego Rady Państwa u Ojca Świętego stała się przełomowa.

Słowa kluczowe: stosunki dyplomatyczne, Polska Rzeczpospolita Ludowa, Stolica Apostolska, Watykan, Jan Paweł II, Wojciech Jaruzelski, Agostino Casaroli, Achille Silvestrini.

$\mathrm{R}$ elacje między Polską Rzeczpospolitą Ludową a Stolicą Apostolską w drugiej połowie lat osiemdziesiątych były bardzo specyficzne ${ }^{1}$. Co prawda, z upływem lat dziewiątej dekady XX w. zintensyfikowano prace nad normalizacją stosunków, jednak mimo wspólnego mianownika motywacje były odmienne. Sprawę dodatkowo komplikowały wydarzenie w Polsce z lat 1981-1984, gdy kontakty bilateralne można określić jako fatalne. Z czego wynikał taki stan?

Patrząc przez pryzmat polityki zagranicznej, wprowadzenie stanu wojennego usytuowało Polskę na marginesie działań międzynarodowych. Polscy dyplomaci znaleźli się w izolacji, ponadto kraj został objęty sankcjami gospodarczymi. Decyzja gen. Wojciecha Jaruzelskiego niemalże z dnia na dzień spowodowała, że polskie stosunki dyplomatyczne zaczęły oscylować w granicach minimalnego poziomu. Efektem był zdecydowany impas w relacjach z państwami Zachodu ${ }^{2}$. Dlatego też podejmowano szereg kroków mających wyprowadzić reżim gen. Jaruzelskiego z owej izolacji, a także pozwolić na pewną legitymizację na arenie stosunków światowych. Szukano różnych pomysłów i kierunków, by wreszcie zwrócić się ku orbicie watykańskiej, szczególnie że w owym czasie papieżem był Polak, co władzom w Warszawie miało ułatwić wszelkie próby w nawiązaniu wzajemnych relacji. Pierwszym krokiem wydawała się II pielgrzymka Ojca Świętego do Polski w 1983 r., lecz nie przyniosła ona oczekiwanych rezultatów. Jan Paweł II nie tylko wskazywał wtedy, że gen. Jaruzelski miał wybór w 1981 r., lecz także jasno podkreślił, że nie będzie mowy o żadnym porozumieniu Kościoła z państwem ponad głowami polskiego Episkopatu oraz braku poszanowania i uznania „Solidarności” ${ }^{3}$. Następnym wydarzeniem, bardzo mocno psującym relacje

1 W tym miejscu trzeba mieć na uwadze to, że nie istniały one formalnie, ponieważ w wyniku wypowiedzenia konkordatu 12 IX 1945 r. przez władze polskie zostały zerwane stosunki dyplomatyczne. Jednakże z racji na ogromne znaczenie Kościoła katolickiego w Polsce i na świecie niemożliwy był zupełny brak kontaktu ze Stolicą Apostolską. Dlatego po wielu trudach, w 1974 r., powołano Zespół ds. Stałych Kontaktów Roboczych między Rządem PRL a Stolicą Apostolską. Już sama nazwa wskazuje na charakter oraz skomplikowanie owych relacji.

2 W. Materski, Bilans okresu, [w:] Historia dyplomacji polskiej, t. VI (1944/1945-1989), red. W. Materski, W. Michowicz, Warszawa 2010, s. 937.

3 G. Weigel, Świadek nadziei. Biografia papieża Jana Pawta II, Kraków 2005, s. 588. 
PRL ze stroną kościelną było zabójstwo ks. Jerzego Popiełuszki 19 października 1984 r. Co prawda, zabójcy zostali postawieni przed sądem oraz skazani w procesie, odbywającym się w lutym 1985 r. ${ }^{4}$, lecz morderstwo pogorszyło relacje państwa z Kościołem, co rzutowało na kontakty Warszawa-Watykan'.

Jednakże izolacja PRL na arenie międzynarodowej nadal się utrzymywała, stąd od pewnego czasu w kręgach polskich władz narastała koncepcja intensyfikacji wszelakich działań zogniskowanych wokół problemu normalizacji stosunków między PRL a Stolicą Apostolską. Zastanawiano się, w jaki sposób można by najlepiej poruszyć tę kwestię, z jednoczesnym pominięciem zaciętego wroga władzy ludowej, jakim jawił się polski Episkopat. Stąd powstała idea bezpośredniej, oficjalnej wizyty rządzących w Watykanie. Dzięki temu udałoby się w sposób najbardziej klarowny wyłożyć polskie racje, które istniały wokół problemu ponownego nawiązania relacji samemu papieżowi, a przede wszystkim zabieg ten ominąłby hierarchów w kraju. Trzeba mieć na uwadze, że ten ostatni postulat był najważniejszy do spełnienia dla Komitetu Centralnego Polskiej Zjednoczonej Partii Robotniczej (dalej: PZPR). Warto zatem przyjrzeć się, jak wyglądały przygotowania do wizyty generała w Watykanie, jaka towarzyszyła jej aura, wreszcie skupić się na jej przebiegu i skutkach, które za sobą niosła.

Artykuł podejmuje kwestię wizyty gen. Jaruzelskiego w Watykanie, która odbyła się na początku 1987 r. W znacznym stopniu, ze względu na zachowane i omówione źródła, skupiono się na przedstawieniu towarzyszących jej przygotowań. Tekst ten stanowi fragment badań prowadzonych przez autora na temat ponownego nawiązania stosunków dyplomatycznych między Polską a Stolicą Apostolską w 1989 r. Problematyka normalizacji stosunków zachodzących na linii Warszawa-Watykan w latach osiemdziesiątych XX w. nie była dotąd podejmowana w dyskursie naukowym. Można stwierdzić, że niemal zupełnie nikt nie interesował się tym zagadnieniem. Wyjątek stanowi artykuł Pawła Kowala ${ }^{6}$, w którym autor pobieżnie ilustruje pewne wydarzenia, a wizycie gen. Jaruzelskiego za Spiżową Bramą poświęca niewiele miejsca, nie podejmując kwestii omówienia bezpośredniej rozmowy gen. Wojciecha Jaruzelskiego z papieżem Janem Pawłem II. Najważniejsze biografie Ojca Świętego także nie przynoszą szczegółowego opisu wizyty generała u Ojca Świętego, poza kronikarskim wspomnieniem . Również tekst Zygmunta Zielińskiego, stanowiący fragment monumentalnej Historii dyplomacji polskiej, kompletnie pomija wątek wizyty. Ponadto bardzo lakonicznie ujmuje wydarzenia lat osiemdziesiątych XX. z zakresu relacji polsko-watykańskich ${ }^{8}$. Artykuł ten jest zatem

$4 \quad$ Był to zresztą pierwszy taki przypadek w państwie komunistycznym, że sprawcy mordu na kapłanie zostali osądzeni i skazani na wieloletnie wyroki więzienia.

5 B. Kumor, Historia Kościota, t. VIII (Czasy wspótczesne 1914-1992), Lublin 2001, s. 532.

6 P. Kowal, Sprawa wznowienia stosunków dyplomatycznych ze Stolica Apostolską w latach 1986-1989, „Polski Przegląd Dyplomatyczny” 2009, nr 2(48), s. 94-99.

Cf. J. Moskwa, Droga Karola Wojtyty, t. II (Zwiastun wyzwolenia 1978-1989), Warszawa 2011, s. 392-393; G. Weigel, op. cit., s. 667-669.

$8 \quad$ Cf. Z. Zieliński, Dyplomacja polska wobec Watykanu w latach 1945-1989, [w:] Historia dyplomacji polskiej..., s. 894-929. 
pierwszą naukową próbą zilustrowania tytułowego wydarzenia i osadzenia go w kontekście normalizacji relacji bilateralnych między Polską a Stolicą Apostolską.

Podstawę źródłową stanowią materiały znalezione przez autora w wyniku kwerendy w Archiwum Ministerstwa Spraw Zagranicznych w Warszawie oraz Archiwum Akt Nowych w Warszawie. Niezwykle interesujące są także materiały strony kościelnej, czyli zbiór dokumentów i notatek ks. Alojzego Orszulika wydany przez niego samego w 2006 r. ${ }^{9}$ Ponadto wykorzystano źródła audiowizualne, a konkretnie materiały Polskiej Kroniki Filmowej dotyczące wizyty gen. Wojciecha Jaruzelskiego w Watykanie.

\section{Długi proces rozmów i przygotowań do wizyty gen. Wojciecha Jaruzelskiego w Watykanie}

Aby dobrze zrozumieć kontekst wizyty Wojciecha Jaruzelskiego w Watykanie w styczniu 1987 r., należy prześledzić niezwykle ciekawy proces przygotowań do niej. W tym celu trzeba cofnąć się o półtora roku, zauważając, że starania związane z możliwym spotkaniem gen. Wojciecha Jaruzelskiego z Ojcem Świętym podjęto już w lipcu 1985 i roku następnym. Łączyło się to nierozerwalnie z intensyfikacją kontaktów ze Stolicą Apostolską ${ }^{10}$. W środowisku skupionym wokół Ministerstwa Spraw Zagranicznych (dalej: MSZ) dojrzewała koncepcja, aby powołane w 1974 r. stałe kontakty robocze ze Stolicą Apostolską przekształcić w normalne i trwałe stosunki dyplomatyczne ${ }^{11}$.

Jak wspomniano, ideę takiej wizyty polskie władze rozważały już w połowie $1985 \mathrm{r}$. Pierwsza rozmowa w tej sprawie odbyła się 20 lipca 1985 r. między księdzem arcybiskupem Bronisławem Dąbrowskim ${ }^{12}$ i księdzem Alojzym Orszulikiem ${ }^{13}$ a gen. Czesławem Kiszczakiem w siedzibie Ministerstwa Spraw Wewnętrznych (dalej: MSW). Minister zapytał wtedy, jakie są możliwości, aby gen. Jaruzelski mógł przybyć do Watykanu już we wrześniu. Jak wspomina ks. Orszulik ${ }^{14}$, zarówno on, jak i abp Dąbrowski byli

9 A. Orszulik, Czas przetomu. Notatki ks. Alojzego Orszulika z rozmów z wtadzami PRL w latach 1981-1989, Warszawa-Ząbki 2006.

10 P. Kowal, op.cit., s. 86.

11 Ibidem.

12 Abp Bronisław Dąbrowski (1917-1997) pełnił przez wiele lat funkcję sekretarza generalnego Konferencji Episkopatu Polski. Brał aktywny udział w wielu rozmowach z władzami PRL. Ponadto jego kontakty nie ograniczały się do relacji między Kościołem a państwem, lecz także był ważną postacią w procesie normalizacji stosunków między Polską a Stolicą Apostolską.

13 Ks. Alojzy Orszulik (1928-2019) odegrał znaczącą rolę w stosunkach państwo-Kościół oraz PRL-Stolica Apostolska. W Episkopacie pełnił funkcję kierownika Biura Prasowego w latach 19681993. Został członkiem Komisji Wspólnej Przedstawicieli Rządu i Episkopatu, a także Komisji Mieszanej Stolicy Apostolskiej i Episkopatu Polski, której celem było nawiązanie stosunków dyplomatycznych między Watykanem a Polską. Brał udział w rozmowach w Magdalence oraz podczas obrad Okrągłego Stołu.

14 W tamtym czasie był jeszcze księdzem. Biskupem został mianowany 8 IX 1989 r., jako biskup pomocniczy diecezji siedleckiej. Następnie, kiedy papież Jan Paweł II erygował diecezję łowicką, Orszulik 
zaskoczeni tym pytaniem, ponieważ niecały miesiąc wcześniej, 22 czerwca 1985 r., za Spiżową Bramę udał się ówczesny minister spraw zagranicznych Stefan Olszowski ${ }^{15}$ i podczas wizyty nie zasygnalizował w ogóle tej kwestii ani papieżowi, ani żadnemu z dyplomatów watykańskich ${ }^{16}$. Tym większe ma to znaczenie, że kręgi kościelne sugerowały Ojcu Świętemu możliwość wysunięcia, przez szefa polskiej dyplomacji, propozycji wizyty najwyższych polskich władz. Jak zauważyli przedstawiciele Episkopatu, w ich mniemaniu powstało wrażenie, jakoby Olszowski albo nie miał odpowiedniego upoważnienia do poruszenia tej kwestii, co niewątpliwie stawiałoby polskie władze w nie najlepszym świetle, albo nie chciał w ogóle podejmować tej problematyki, bądź też istniała jakaś dwutorowośćc ${ }^{17}$. Wydaje się, że Episkopat najbardziej obawiał się tej trzeciej opcji, ponieważ oznaczałoby to zakulisowe rozmowy mające na celu pominięcie polskiej hierarchii z dyskursu zogniskowanego wokół ewentualnego wyjazdu przewodniczącego Rady Państwa. Mimo to do Kurii watykańskiej dotarły informacje z prasy, która spekulowała na temat planowanej wizyty gen. Jaruzelskiego u Jana Pawła II. W związku z tym wysłannicy Episkopatu przekazali ministrowi Czesławowi Kiszczakowi, że Watykan traktował te wiadomości niepoważnie (ponieważ trudno, aby Stolica Apostolska miała się dowiadywać z mediów o tak ważnej wizycie, bez rozmów z dyplomacją polską), a do kręgu papieskiego dostały się jedynie informacje na temat planowanej podróży sekretarza Komitetu Centralnego oraz członka Rady Państwa Kazimierza Barcikowskiego. Zresztą, jak zaznaczył ks. Orszulik, potwierdził je ambasador PRL w Rzymie Józef Wiejacz, dodając nawet, że wiadomości o rzekomej wizycie gen. Jaruzelskiego były zupełnie nieuzasadnione ${ }^{18}$.

W reakcji na te słowa minister spraw wewnętrznych powiedział, że faktycznie Olszowski nie miał upoważnienia ze strony aktywu rządowego do podejmowania owej tematyki, ponieważ polskie władze uznały, że lepiej byłoby „załatwić” wizytę Jaruzelskiego kanałem kościelnym. Według Kiszczaka chodziło też o wysondowanie przez dyplomację watykańską, czy premier Włoch Bettino Craxi byłby w stanie zaprosić generała w tym czasie do Rzymu ${ }^{19}$. Jak zasugerowano, do kościelnego kanału informacyjnego można by wykorzystać prałata Stanisława Dziwisza, będącego jednocześnie osobistym sekretarzem Ojca Świętego, który niedawno przyjechał do Krakowa na wakacje $^{20}$. Kiszczak wspomniał o tym, że wizyta mogłaby się odbyć w dniach 30 września 1 października 1985 r. Termin ten powiązany został z wrześniowym posiedzeniem

został jej pierwszym biskupem (25 III 1992 r.). Dnia 22 V 2004 r. przeszedł na emeryturę. Zmarł 21 II 2019 r. $C f$. https://episkopat.pl/zmarl-bp-alojzy-orszulik-pierwszy-biskup-lowicki/ (dostęp: 26 VI 2019).

15 Stefan Olszowski (ur. 1931) pełnił funkcję ministra spraw zagranicznych w latach 1971-1976 oraz 1982-1985.

16 Będzie wizyta Jaruzelskiego w Watykanie. Sprawozdanie z rozmowy ks. abp. B. Dąbrowskiego i ks. A. Orszulika z gen. Czestawem Kiszczakiem 20 lipca 1985 w MSW, [w:] A. Orszulik, op.cit., s. 222.

17 Ibidem, s. 222-223.

18 Ibidem, s. 223.

19 Ibidem.

20 P. Kowal, op. cit., s. 94. 
Zgromadzenia Ogólnego Organizacji Narodów Zjednoczonych (dalej: ONZ) w Nowym Jorku (podczas którego, 27 września gen. Jaruzelski miałby wystąpienie) oraz wizytą na Kubie. Plan zakładał, że 28 września delegacja polska odleciałaby specjalnym samolotem do Warszawy via Rzym. Ksiądz Orszulik i arcybiskup Dąbrowski wyraźnie zaakcentowali, że nie jest dobrym pomysłem, aby przyjazd przewodniczącego Rady Państwa do stolicy Włoch miał nastąpić z Kuby. O wiele lepszą koncepcją byłby wylot bezpośrednio ze Stanów Zjednoczonych. Jak to należy rozumieć? Z pewnością dla światowej opinii publicznej zdecydowanie bardziej przemawiające byłoby, gdyby gen. Jaruzelski spotkał się z papieżem bezpośrednio po szczycie ONZ niż w drodze powrotnej od Fidela Castro. Przez to sama wizyta miałaby w swym przekazie pewien inny ładunek emocjonalny, a przede wszystkim wizerunkowy. Następnie podczas opisywanego spotkania ustalono, że strona kościelna skontaktuje się z ks. Dziwiszem, wykorzystując do tego kard. Franciszka Macharskiego ${ }^{21}$.

Dnia 24 lipca 1985 r. w rezydencji arcybiskupów krakowskich odbyło się spotkanie ks. Orszulika z kard. Macharskim oraz ks. prałatem Dziwiszem. Podczas dyskusji metropolita krakowski zauważył, że konieczne jest, aby z dyplomacją watykańską kontaktował się bezpośrednio przedstawiciel gen. Jaruzelskiego. Zabieg ten, według kardynała, był niezbędny, aby opinia publiczna nie myślała, że to papież prosi o spotkanie władze polskie ${ }^{22}$, a przez to obraz całości rokowań byłby mocno zdeformowany.

W trakcie rozmowy ustalono kilka ważnych szczegółów. Po pierwsze, ks. Dziwisz zobowiązał się przekazać wszystkie informacje Ojcu Świętemu oraz odpowiednim pracownikom Kurii Rzymskiej. Zdecydowano się na uruchomienie odpowiedniego kanału kościelnego w postaci abp. Achillego Silvestriniego ${ }^{23}$ bądź jego zastępcy. Najwięcej wątpliwości wzbudził termin, który określono jako zły. Także prasa włoska bardzo źle wyrażała się o polskiej polityce wewnętrznej, uważając, że w głównej mierze to ona torpedowała całość zabiegów zagranicznych ${ }^{24}$. Dość mocno obawiano się, że rząd włoski nie byłby chętny do wystosowania zaproszenia dla władz w Polsce, a bez pokonania tej protokolarnej przeszkody oficjalna wizyta nie mogłaby się odbyćc ${ }^{25}$. Na sprawę daty niekorzystnie wpływał fakt, że dopiero 1 sierpnia 1985 r. prałat Dziwisz miał wrócić do Rzymu. Uczestnicy uznali, że wszystkie przygotowania należało zachować w ścisłej tajemnicy, aż do ostatniego momentu. Ponadto Jan Paweł II pomagałby przełamać istniejącą na świecie (myślano szczególnie o rządzie włoskim) izolację moralną, polityczną i ekonomiczną wobec Polski ${ }^{26}$.

21 Będzie wizyta..., s. 224.

22 O czym Kiszczak powinien wiedzieć. Notatka z rozmowy z ks. kard. F. Macharskim i ks. prat. S. Dziwiszem $w$ Krakowie w dniu 24 lipca 1985, [w:] A. Orszulik, op. cit., s. 226-227.

23 Abp Achille Silvestrini (1923-2019) był wysokim urzędnikiem Sekretariatu Stanu Stolicy Apostolskiej, w którym odpowiadał za relacje z państwami. W 1988 r. Jan Paweł II wyniósł Silvestriniego do godności kardynalskiej.

24 Ibidem, s. 227.

25 Cf. D. Morawski, Korespondencja z Rzymu, „Kultura” 1987, nr 3(474), s. 77.

26 O czym Kiszczak..., s. 227. 
Następnego dnia odbyło się kolejne spotkanie w siedzibie MSW. Brały w nim udział te same trzy osoby co 20 lipca. Najpoważniejszą a zarazem najtrudniejszą sprawą było to, czy premier Craxi byłby gotów zaprosić gen. Jaruzelskiego do Włoch. Ambasador Republiki Włoskiej w Polsce Guglielmo Folchi stwierdził, że w bieżącym roku nie będzie możliwa wizyta najwyższych polskich władz w jego ojczyźnie. Jak słusznie zauważył minister Kiszczak, wypowiedź ta była o tyle symptomatyczna, że przecież ambasador z pewnością działał w myśl dyrektyw, które otrzymywał od włoskiego MSZ. Komunistyczny dygnitarz zaznaczył również, że sprawę komplikowała konieczność prowadzenia rozmów wokół zgody na wizytę w formie „dyskusyjnego wieloboku”27. Według ocen polskich władz strona włoska na pewno konsultowała się w tej sprawie z sojusznikami z Organizacji Traktatu Północnoatlantyckiego (NATO) ${ }^{28}$. W wyniku takich wniosków i stanowiska ambasadora Folchiego sprawa wrześniowej wizyty w Watykanie upadła. Szybko pojawił się pomysł, aby raz jeszcze spróbować zorganizować w Rzymie przystanek samolotu delegacji polskiej na trasie z jednego punktu do drugiego. W tym przypadku chodziło o przelot z Polski do Afryki. I ta koncepcja szybko stała się nieaktualna, ponieważ nie było gotowości strony włoskiej do wystosowania zaproszenia. Można wnioskować, że kręgi watykańskie także niechętnie patrzyły na możliwość przyjęcia delegacji, która udawała się w podróż na kontynent afrykański.

W kolejnych miesiącach kwestia związana z ewentualną wizytą generała nie została skierowana na boczny tor. Można wręcz dostrzec większą determinację w rozmowach i zabiegach dyplomatycznych. Interesująco w omawianym kontekście brzmi fragment depeszy Jerzego Kuberskiego ${ }^{29}$ do ministra spraw zagranicznych Mariana Orzechowskiego z kwietnia 1986 r. Kierownik Zespołu ds. Stałych Kontaktów Roboczych między Rządem PRL a Stolicą Apostolską wspominał, że nadal istniała niechęć wśród włoskich kręgów rządowych w sprawie możliwości zaproszenia do kraju oficjalnej delegacji polskiej pod przewodnictwem gen. Jaruzelskiego. Kuberski zaznaczył, że demonstrowana przez papieża i Sekretariat Stanu chęć spotkania z przywódcą PRL jest bezprecedensowa, jeśli chodzi o wyrażanie nacisku na władze włoskie ${ }^{30}$. Autor depeszy napisał także, że w jego opinii sprawa wizyty generała we Włoszech i Watykanie to tylko kwestia czasu i wyboru właściwego momentu.

${ }^{27}$ Chodziło tutaj nie tylko o rozmowy między Republiką Włoską a PRL, lecz także między Republiką Włoską a Stolicą Apostolską oraz PRL a Stolicą Apostolską. Dlatego też negocjacje w kwestii wizyty nie były proste i się przeciągały.

28 Generat zapisuje i obiecuje. Sprawozdanie z rozmowy ks. abp. B. Dabrowskiego i ks. A. Orszulika z gen. Czestawem Kiszczakiem, [w:] A. Orszulik, op. cit., s. 229.

29 Jerzy Kuberski (1930-2007) pełnil funkcję ministra-kierownika Urzędu do Spraw Wyznań w latach 1980-1982. Był kierownikiem Zespołu ds. Stałych Kontaktów Roboczych między Rządem PRL a Stolicą Apostolską. Kiedy doszło do normalizacji stosunków dyplomatycznych na linii WarszawaWatykan w 1989 r., został ambasadorem rządu RP przy Stolicy Apostolskiej. 
Po raz kolejny problem wizyty polskiej delegacji w Watykanie powrócił w połowie 1986 r., podczas rozmów przygotowawczych wizyty Jana Pawła II w Polsce. Władze PRL uczyniły z niej warunek jakichkolwiek dalszych działań pielgrzymkowych w stosunku do Ojca Świętego. Mimo to strona watykańska nie mogła w sposób skuteczny wpłynąć na rząd włoski, co tylko potęgowało poirytowanie w szeregach polskich polityków. W końcu po wielu próbach udało się ustalić możliwość zaproszenia ze strony władz Republiki Włoskiej. Negocjatorem w tych kwestiach był Luigi Poggi, który sprawował funkcję nuncjusza apostolskiego przy Kwirynale i osobiście rozmawiał z Francesco Cossigą, prezydentem Włoch. Takie posunięcie było najprawdopodobniej podyktowane bezpośrednim poleceniem papieża ${ }^{31}$.

Warto w tym miejscu przywołać interesującą rozmowę między abp. Bronisławem Dąbrowskim a Czesławem Kiszczakiem, odbytą w lipcu 1986 r., w czasie której minister spraw wewnętrznych dość stanowczo akcentował, że władzę mocno poirytował fakt długiego przeciągania kwestii związanych z możliwością przyjazdu gen. Jaruzelskiego do Watykanu. W oczach Komitetu Centralnego PZPR wyglądało to na celową zagrywkę dyplomacji watykańskiej. Ponadto Kiszczak wyraźnie wskazał Dąbrowskiemu, że w rzeczywistości Wojciech Jaruzelski w ogóle nie jest zainteresowany wizytą we Włoszech, a jedynym celem jest w tym wypadku podróż do Stolicy Apostolskiej i bezpośrednie spotkanie się z Janem Pawłem II. Włochy miały być tylko formalnym punktem zaczepienia w kwestiach organizacyjnych. Arcybiskup odpowiedział ministrowi, że to nie kwestia niechęci papieża i jego kręgów stanowi kłopot w procesie ustalania wizyty, lecz niemożność dojścia do porozumienia w tej kwestii między Stolicą Apostolską a rządem włoskim ${ }^{32}$.

Arcybiskup wystarał się w Watykanie o ustalenie wstępnej daty wizyty na drugą dekadę grudnia 1986 r. W wyniku dalszych rozmów prowadzonych z kolei 20 października 1986 r. przez Mariana Orzechowskiego, podczas spotkania w Wiedniu ${ }^{33}$ z abp. Silvestrinim zostało ustalonych sporo szczegółów związanych z wizytą najwyższej rangą delegacji władz polskich w Watykanie. Jednakże nie wszystko było jeszcze odpowiednio zaaprobowane i dopracowane. Dlatego też w tej sprawie udał się do Warszawy nowy nuncjusz apostolski ds. specjalnych poruczeń, jednocześnie kierownik Zespołu ds. Stałych Kontaktów Roboczych między Rządem PRL a Stolicą Apostolską, Francesco Colasuonno ${ }^{34}$. Przybywał on w PRL od 17 listopada do 1 grudnia 1986 r. W tym czasie został przyjęty przez Kazimierza Barcikowskiego - zastępcę przewodniczącego

31 Ibidem, s. 94-95.

32 Ibidem.

33 Spotkanie odbyło się przy okazji szczytu Konferencji Bezpieczeństwa i Współpracy w Europie (dalej: KBWE). Cf. Notatka dot. koncepcji rozmowy min. M. Orzechowskiego (na temat stosunków państwo-Kościół) z abpem A. Silvestrinim, sekretarzem Rady ds. Publicznych Stolicy Apostolskiej, Archiwum Akt Nowych w Warszawie [dalej: AAN], Zespół do spraw Kościoła Rzymskokatolickiego, Wizyta abp Colasuonno 1986, 1988, sygn. 126/53, k. 9.

34 Oczywiście chodzi o kierownika po stronie Stolicy Apostolskiej, gdyż analogiczną funkcję z ramienia rządu PRL sprawował Jerzy Kuberski. 
Rady Państwa ${ }^{35}$, prezesa Rady Ministrów Zbigniewa Messnera, a także ministra spraw zagranicznych Mariana Orzechowskiego ${ }^{36}$ i kierownika Urzędu ds. Wyznań Adama Łopatkę ${ }^{37}$.

Podczas rozmów Colasuonno z Barcikowskim polski polityk zaakcentował konieczność oparcia stosunków państwo-Kościół oraz Polska-Watykan na podstawach realizmu. Rozumiał przez to, że owe relacje układają się poprawnie, lecz istnieje pewna grupa księży, zwłaszcza wśród wyższej hierarchii, która nie tylko burzy wysiłki na rzecz normalizacji, lecz wręcz przeciwnie - godzi w interesy państwowe. Rozpatrując ów aspekt, Episkopat nie podejmując działań w tej dziedzinie, tylko pogarszał sytuację. Jak na końcu zaznaczył zastępca przewodniczącego Rady Państwa, taka postawa szkodziła interesom Kościoła, a ponadto stwarzała bardzo poważną przeszkodę w konstruktywnym dialogu na rzecz normalizacji stosunków. Zbigniew Messner niemalże skopiował to, co powiedział w rozmowie $\mathrm{z}$ arcybiskupem Kazimierz Barcikowski, szczególnie skupiając się na sprzecznej z prawem działalności części kleru, który wykorzystywał do celów politycznych świątynie ${ }^{38}$.

W zupełnie innym tonie wypowiadał się natomiast minister spraw zagranicznych. Orzechowski na początku podkreślił celowość wysiłków podejmowanych przez obydwie strony na rzecz normalizacji stosunków między państwem a Kościołem, a nade wszystko Watykanem a Polską. W tym ostatnim aspekcie zwrócił uwagę, że mające odbyć się spotkanie między gen. Wojciechem Jaruzelskim a papieżem Janem Pawłem II powinno uzyskać najwyższą rangę, by odnieść polityczny sukces ${ }^{39}$. Co prawda, minister nie wyjaśnił, o co mu chodziło w kwestii wspomnianego rezultatu watykańskiej wizyty, można jednak domniemywać, że polskie władze liczyły na niebywały przełom w kwestii styczniowej podróży. Nastawiano się, że w wyniku rozmowy Wojciech Jaruzelski-Jan Paweł II dojdzie do nawiązania stosunków dyplomatycznych Polski ze Stolicą Apostolską. Dlatego też sformułowanie o „politycznym sukcesie” wydaje się mieć jednoznaczną treść.

Jak na te rozmowy reagował arcybiskup Colasuonno? Podkreślił to, co wcześniej padło z ust Poggiego czy Silvestriniego, że Stolica Apostolska opowiada się za rozwojem dialogu z Polską, czego najwyższym etapem miała być pełna normalizacja stosunków dyplomatycznych. To było również życzeniem papieża, któremu, jako Polakowi na

35 Pełnił tę funkcję od 6 XI 1985 do 19 VII 1989 r. Ponadto zasiadał w Komisji Wspólnej Przedstawicieli Rządu i Episkopatu. $C f$. https://katalog.bip.ipn.gov.pl/informacje/485 (dostęp: 26 VI 2019); M. Górska, J. Kuligowski, Kazimierz Barcikowski (1927-2007), drn. ekon., polityk, wicepremier, dziatacz polityczny i spótdzielczy, „Rocznik Mińsko-Mazowiecki” 2007, nr 15, s. 203-206.

36 Marian Orzechowski (1931-2020) był szefem polskiej dyplomacji w latach 1985-1988, zmieniając na tym stanowisku Stefana Olszowskiego.

37 Adam Łopatka (1928-2003) kierował Urzędem ds. Wyznań w latach 1982-1987. Cf. Pilna notatka o wizycie abpa F. Colasuonno w związku z rozpoczęciem jego misji w Polsce, AAN, Zespół do spraw Kościoła Rzymskokatolickiego, Wizyta abp Colasuonno 1986, 1988, sygn. 126/53, k. 1.

38 Ibidem, k. 3, 4 .

39 Ibidem. 
tronie piotrowym, bardzo zależało, od początku pontyfikatu, na relacjach Watykanu z jego ojczyzną. Jednakże u Colasuonno pojawił się element konsekwentnie powtarzany przez niemalże całą dyplomację watykańską z papieżem na czele, że dążenie do normalizacji musi współgrać ze stałym postępem na linii państwo-Kościól. Ponadto rozmowy te nie mogły być toczone ponad głowami polskich hierarchów. Wyraźnie zaznaczone zostało także, że wizyta gen. Jaruzelskiego w Watykanie i jego spotkanie z papieżem byłoby wspaniałą okazją, aby postęp we wzajemnych stosunkach stał się widoczny i namacalny ${ }^{40}$.

Gość watykański powiedział także o kwestiach nurtujących Jana Pawła II. Mogłyby one zostać uregulowane podczas spotkania z przewodniczącym Rady Państwa w Pałacu Apostolskim czy planowanej na kolejny rok III pielgrzymki papieża do Polski. Wśród nich jako najważniejsze Colasuonno wymienit: status prawny Kościoła, problem uznania Papieskich Akademii Teologicznych, zezwolenia na budowę nowych kościołów, cenzurowanie wiadomości kościelnych, w szczególności tekstów Ojca Świętego, czy wreszcie niepokój wynikający z wprowadzania do szkół przedmiotu religioznawstwo. Stanowiło to zagrożenie mieszania religii z polityką przy jednoczesnym krytykowaniu Kościoła katolickiego ${ }^{41}$. Wysłannik papieski wyraził przekonanie, że gdyby w tygodniach poprzedzających podróż udało się pozytywnie załatwić dwie pierwsze z wymienionych spraw, to gen. Jaruzelski zawiózłby papieżowi cenny prezent z okazji Bożego Narodzenia ${ }^{42}$.

Ustalono, że w zakresie merytorycznego przygotowania styczniowego spotkania obydwie strony powinny skupić się na trzech najważniejszych płaszczyznach dialogu: problematyce międzynarodowej, stosunkach państwo-Kościół oraz relacjach między Polską a Stolicą Apostolską ${ }^{43}$.

Tuż po zakończeniu wizyty arcybiskupa Francesco Colasuonno w Warszawie minister spraw zagranicznych opracował specjalną poufną notatkę dotyczącą jego misji w Polsce. Powstała ona w ministerstwie 3 grudnia 1986 r. i rozesłano ją do najważniejszych osób w państwie polskim ${ }^{44}$. W dokumencie tym Marian Orzechowski uznał, że należy opracować potencjalne rozwiązania, które następnie gen. Jaruzelski mógłby przedstawić stronie watykańskiej jako gesty dobrej woli ze strony władz PRL ${ }^{45}$. W tym wypadku postulaty przytoczone przez Colasuonno jawiły się jako idealny materiał do pracy. Szef polskiej dyplomacji podkreślił jednak, że można by uwzględnić te, które nie kolidowały z interesami socjalistycznego państwa. Dlaczego takie działanie planowały władze w Warszawie? Opisywano to jako krok wyprzedzający postulaty, jakie z całą pewnością wysunąłby papież podczas zbliżającego się spotkania ${ }^{46}$.

\footnotetext{
Ibidem.

Ibidem, k. 5.

Ibidem.

Ibidem, k. 6.

Ibidem, k. 1.

Ibidem, k. 7.

Ibidem, k. 8.
} 
Z wizytą poprzedzającą wyjazd gen. Jaruzelskiego do Rzymu i Watykanu pojechał w pierwszych dniach stycznia szef Biura Ochrony Rządu (dalej: BOR), gen. Olgierd Darżynkiewicz. Celem było zrobienie odpowiedniego rekonesansu przed przyjazdem polskich władz, ale istotniejszy był punkt dotyczący planowanej pielgrzymki Jana Pawła II do Polski. W tym celu odbyło się spotkanie z o. Robertem Tuccim SJ ${ }^{47}$, których uczestnikiem był także ks. Alojzy Orszulik. Szef BOR tłumaczył niemożność doprowadzenia do skutku papieskiej wizyty, mówiąc, że Polska nie miała odpowiedniej liczby środków transportów, zwłaszcza helikopterów. Te, które były do dyspozycji, to maszyny niebezpieczne i przestarzałe, bądź też wojskowe. Według opinii wysuniętej przez gen. Darżynkiewicza nie wypadało przecież papieża transportować uzbrojonym helikopterem. Rezultat tych dyskusji był żaden ze względu na mocno kuriozalne wypowiedzi szefa BOR. Stąd też zarówno o. Tucci, jak i ks. Orszulik zdecydowali się kontynuować dialog w Warszawie, gdzie udali się specjalnym samolotem 6 stycznia 1987 r. Tam jednak trwał impas ${ }^{48}$. Dziwić może jednak fakt tak otwartego i niechętnego nastawienia rządu w sprawie wizyty apostolskiej Jana Pawła II w ojczyźnie, w przededniu bezpośredniego spotkania na szczycie delegacji polskiej i watykańskiej. Przychodzą na myśl dwa wytłumaczenia. Pierwsze może stanowić o nieodpowiedniej wiedzy gen. Darżynkiewicza w kwestiach planowanych rozmów między gen. Jaruzelskim a papieżem, co nie jest wiarygodnym wytłumaczeniem, szczególnie jeśli pojechał on dopinać organizacyjne szczegóły spotkania. Druga możliwość to celowa polityka władz PRL, która dążyła do skłaniania Stolicy Apostolskiej do dużej elastyczności i zgadzania się na pewne postulaty polskich władz w zamian za ustępstwa drugiej strony.

Interesujący dokument poprzedzający wizytę delegacji polskiej w Watykanie powstał w Wydziale Propagandy Komitetu Centralnego PZPR 10 grudnia 1986 r. Poruszone w nim zostały nie tylko kwestie organizacyjne samej wizyty, lecz przede wszystkim wiele zabiegów na gruncie medialnym, zarówno w Polsce, jak i za granicą. Dlatego też niepoślednią rolę przypisywano TVP, Polskiemu Radiu (Program I i Program III) ${ }^{49}$, Polskiej Agencji Prasowej czy agencji Interpress.

Oficjalny komunikat zapowiadający wizytę gen. Jaruzelskiego we Włoszech i Watykanie miał być nadany w TVP 20 grudnia 1986 r. Telewizja Polska miała następnie przedstawić system polityczny Włoch, w którym funkcja premiera dawała wyłączność

Robert Tucci SJ, jezuita, organizator pielgrzymek Jana Pawła II. Do roku 2001 towarzyszył papieżowi podczas niemal każdej pielgrzymki zagranicznej. W tym samym roku został podniesiony do godności kardynalskiej.

48 A. Orszulik, Droga do petnej normalizacji stosunków między państwem a kościotem oraz między PRL a Stolica Apostolską, „Politeja. Pismo Wydziału Studiów Międzynarodowych i Politologicznych Uniwersytetu Jagiellońskiego” 2014, t. XXIX, s. 334.

49 Zapis dyskusji z udziałem przedstawicieli Wydz. Zagranicznego KC, MSZ, Urzędu ds. Wyznań, Samodzielnego Zespołu Analiz przewodniczącego Rady Państwa, PR, PAP, PA „Interpress” na temat oprawy informacyjno-propagandowej oficjalnej wizyty przewodniczącego Rady Państwa PRL gen. W. Jaruzelskiego we Włoszech i Watykanie, AAN, Zespół do spraw Kościoła Rzymskokatolickiego, Wizyta tow. Wojciecha Jaruzelskiego w Watykanie 13 I 1987. Przygotowania, przebieg, komentarze. 1986-1987, sygn. 126/52, k. 28, 34, s. 2,8 . 
na prowadzenie polityki zagranicznej, a prezydent pełnił tylko funkcje protokolarne ${ }^{50}$. Dlaczego to było istotne? Wszystko rozbijało się o komentarze środowisk nieprzychylnych władzom PRL, w szczególności tych, które próbowały obniżyć rangę wizyty ze względu na zaproszenie przewodniczącego Rady Państwa przez premiera Craxiego, a nie prezydenta Cossigę. Nie brakowało materiałów o charakterze gospodarczych powiązań, chociażby w kontekście koncernu FIAT $^{51}$.

Miało to działać również w drugą stronę. Tematyka polska widoczna była we włoskich środkach masowego przekazu, tj. RAI czy „La Repubblica” ${ }^{2}$. Zaplanowano także spotkanie wybranych włoskich dziennikarzy w polskiej ambasadzie w Rzymie w celu ukazania wzajemnych stosunków oraz polskiej polityki wewnętrznej ${ }^{53}$.

W kontekście wizyty polskich władz za Spiżową Bramą uważano, że w dyskursie propagandowym należy kłaść bardzo duży nacisk na akcentowanie stosunku papieża w kwestii pokoju światowego. Najbardziej interesujące wydaje się jednak, że w kręgach władz i telewizyjnych decydentów wysunięto postulat, aby przeprowadzić transmisję na żywo bądź przynajmniej retransmisję „pasterki” bezpośrednio z Bazyliki św. Piotra w Watykanie ${ }^{54}$. Nie ulega wątpliwości, że miał być to zabieg pokazujący dobrą wolę polskiego rządu w stosunku do papieża, Kościoła katolickiego oraz pośrednio społeczeństwa w kraju.

Kolejnym ważnym elementem była sprawa akredytacji dziennikarzy mających obsługiwać prasowo-informacyjny aspekt wizyty w Rzymie i Watykanie. Wydział Propagandy proponował 25-osobową grupę, w skład której obowiązkowo weszłoby przynajmniej pięciu dziennikarzy reprezentujących prasę katolicką. To miało zapewnić pewien parytet, a spora grupa przedstawicieli prasy powinna zbierać jak najwięcej materiałów, aby móc stworzyć następnie odpowiednie przekazy, np. w TVP specjalne filmy poświęcone wizycie, w Polskiej Agencji „Interpress” ilustrowana pozycja dedykowana w całości wizycie Wojciecha Jaruzelskiego w Watykanie ${ }^{55}$, a w Polskiej Kronice Filmowej obszerny film dokumentalny z tego wydarzenia. Ostatni element stanowić miało wystąpienie rzecznika prasowego rządu PRL Jerzego Urbana ustalone na 20 stycznia 1987 r., w którym przedstawiłby on ocenę przebiegu i rezultatów minionej wizyty ${ }^{56}$.

\footnotetext{
Ibidem, k. 27, s. 1.

Ibidem, k. 28, s. 2.

52 W dokumencie Wydziału Propagandy KC PZPR jest błąd w pisowni, ponieważ zapisano tam „La Republica". Ibidem, k. 30, s. 4.

53 Ibidem.

54 Ibidem, k. 28, 31, s. 2, 5.

55 Faktycznie taka pozycja się ukazała w 1987 r. nakładem Polskiej Agencji „Interpress”. Cf. Wizyta w Watykanie. 13 stycznia 1987 roku, red. W. Machowski, Warszawa 1987.

56 Zapis dyskusji z udziałem przedstawicieli Wydz. Zagranicznego KC, MSZ, Urzędu ds. Wyznań, Samodzielnego Zespołu Analiz przewodniczącego Rady Państwa, PR, PAP, PA „Interpress” na temat oprawy informacyjno-propagandowej oficjalnej wizyty przewodniczącego Rady Państwa PRL gen. W. Jaruzelskiego we Włoszech i Watykanie, AAN, Zespół do spraw Kościoła Rzymskokatolickiego, Wizyta tow. Wojciecha Jaruzelskiego w Watykanie 13 I 1987. Przygotowania, przebieg, komentarze. 1986-1987, sygn. $126 / 52$, k. 28,35 , s. 2,8 .
} 
W ramach przygotowań polskiej delegacji istotną rolę odgrywała dyskusja nad prezentem, jaki miał przekazać Wojciech Jaruzelski papieżowi. Pierwsze propozycje przesłał Edward Kotowskii ${ }^{57}$, będący ówcześnie pracownikiem Urzędu ds. Wyznań i jednocześnie funkcjonariuszem Służby Bezpieczeństwa. Ostatecznie decyzję podjęto 31 grudnia 1986 r. ${ }^{58}$ Generał Jaruzelski podczas spotkania z papieżem wręczył Janowi Pawłowi II obraz przedstawiający krajobraz jego rodzinnych Wadowic autorstwa Michała Klisia oraz komplet płyt z ostatniego konkursu chopinowskiego ${ }^{59}$. Ojciec Święty był bardzo zadowolony z obrazu przedstawiającego jego rodzinną miejscowość, tym bardziej że pejzaż ukazywał również dom jego urodzenia i kościół, z którym był związany od dziecka. Z kolei delegacja polska otrzymała od papieża dwa albumy barwnych reprodukcji fresków z Kaplicy Sykstyńskiej, które dopiero co zostały odnowione przez japońskich specjalistów. Ponadto przewodniczący Rady Państwa otrzymał tryptyk medali pontyfikatu Jana Pawła II, sporządzonych w złocie, srebrze i brązie ${ }^{60}$.

\section{Wizyta gen. Wojciecha Jaruzelskiego w Watykanie}

W podróż do Włoch i Watykanu udała się polska delegacja w składzie: przewodniczący Rady Państwa Wojciech Jaruzelski, członkowie Biura Politycznego: sekretarz KC Józef Czyrek, minister spraw zagranicznych Marian Orzechowski, wiceprezes Rady Ministrów Zbigniew Szałajda, członek Rady Państwa Witold Lipski, minister kultury i sztuki Aleksander Krawczuk oraz minister-kierownik ds. Wyznań Adam Łopatka. W skład osób towarzyszących wszedł również kierownik Zespołu ds. Stałych Kontaktów Roboczych między Rządem PRL i Stolicą Apostolską, minister Jerzy Kuberski ${ }^{61}$.

Oficjalna wizyta polskiej delegacji do Włoch i Watykanu rozpoczęła się 12 stycznia o godzinie 11.00, gdy samolot Polskich Linii Lotniczych LOT wylądował na rzymskim lotnisku Ciampino ${ }^{62}$. Na włoskiej ziemi przedstawicieli polskiej delegacji przywitali premier Włoch Bettino Craxi oraz przedstawiciele Stolicy Apostolskiej. Następnym punktem programu było złożenie kwiatów przez gen. Jaruzelskiego razem z włoskim ministrem obrony Giovannim Spadolinim na Grobie Nieznanego Żołnierza zlokalizowanym w Monumento Nazionale przy Placu Weneckim w Rzymie. Kolejnym, kurtuazyjnym punktem programu było udanie się na jedno z siedmiu wzgórz rzymskich - Kwirynał, gdzie znajduje się pałac będący rezydencją prezydentów Włoch. Stąd też gościa z Warszawy witała głowa państwa Francesco Cossiga ${ }^{63}$.

\footnotetext{
57 Propozycje prezentu przewodniczącego Rady Państwa dla Papieża, ibidem, k. 19, 20.

58 Ibidem, k. 21.

59 PKF 4/87, Znad Tybru, http://www.repozytorium.fn.org.pl/?q=pl/node/8797 (dostęp: 28 I 2019).

60 Wizyta w Watykanie..., s. 14-15.

61 Notatka o wizycie przewodniczącego Rady Państwa PRL Wojciecha Jaruzelskiego w Watykanie (13 I 1987), Archiwum Ministerstwa Spraw Zagranicznych w Warszawie [dalej: AMSZ], PRL-Watykan, 1987, 32/90, wiązka I, D IV Wat. 0-22-1-87, s. 1.

62 PKF 4/87, Znad Tybru, http://www.repozytorium.fn.org.pl/?q=pl/node/8797 (dostęp: 28 I 2019).

63 Ibidem.
} 
Po południu, o godzinie 17.00 nastąpiło trzygodzinne spotkanie delegacji polskiej z premierem Craxim w Pałacu Chigi ${ }^{64}$. Jak podkreślił włoski polityk, była to pierwsza oficjalna wizyta gen. Jaruzelskiego we Włoszech, lecz drugie spotkanie obu panów, gdyż pierwsze odbyło się w Warszawie w maju $1985 \mathrm{r}^{65}$ Równolegle rozmawiali ze sobą nie tylko przewodniczący Rady Państwa z prezesem Rady Ministrów Włoch, lecz także ministrowie spraw zagranicznych Marian Orzechowski z Giulio Andreottim ${ }^{66}$. Głównym tematem rozmów między Jaruzelskim a Craxim była sytuacja w Europie, stan stosunków między Wschodem a Zachodem i dwustronna współpraca obydwu państw. Rozmowy obejmowały zatem płaszczyzny związane z pokojem, rozbrojeniem, handlem, gospodarką i kulturą. Pierwsze dwie kwestie omawiane były także w kontekście KBWE, która dla obydwu stron stanowiła bardzo ważne forum ${ }^{67}$. Później w „Grand Hotelu" przy Via Orlando doszło do spotkania Jaruzelskiego z sekretarzem generalnym Włoskiej Partii Komunistycznej Alessandro Nattą ${ }^{68}$.

Następnego dnia, 13 stycznia 1987 r. odbyła się wizyta, która została okrzyknięta mianem „historycznej”. Parę minut po godzinie 11.00 samochód z proporczykiem przewodniczącego Rady Państwa przekroczył w eskorcie specjalnego watykańskiego pojazdu ze znakami „SCV"69 Spiżową Bramę i podjechał pod wejście do Pałacu Apostolskiego ${ }^{70}$. Wizyta gen. Jaruzelskiego w Watykanie trwała łącznie trzy i pół godziny, co przekraczało nawet dotychczasowe precedensy przy okazji wizyt innych głów państw, nie wspominając już o protokolarnym trybie. Konieczne jest wspomnienie, że protokół watykański w wewnętrznym rozporządzeniu nadał wizycie polskiego przywódcy najwyższy stopień protokolarny molto solenne ${ }^{71}$. Powitanie wśród asysty gwardzistów szwajcarskich czynił prefekt domu papieskiego, kard. Dino Monduzzi ${ }^{72}$. Następnie w prywatnej bibliotece papieskiej doszło do bezpośredniego spotkania między gen. Wojciechem Jaruzelskim a papieżem Janem Pawłem II. Było to pierwsze oficjalne spotkanie przewodniczącego Rady Państwa z Ojcem Świętym za czasów pontyfikatu Karola Wojtyły ${ }^{73}$. Rozmowa w cztery oczy trwała bardzo długo, dokładnie 74 minu$\mathrm{ty}^{74}$. Standardowo zaś wiele uroczystych i formalnych audiencji papieskich zamykało

64 AAN, Zespół do spraw Kościoła Rzymskokatolickiego. Wizyta tow. Wojciecha Jaruzelskiego w Watykanie 13 I 1987. Przygotowania, przebieg, komentarze. 1986-1987, sygn. 126/52, k. 44.

65 Ibidem, k. 39.

66 Ibidem, k. 44.

67 Ibidem, k. 45.

68 PKF 4/87, Znad Tybru, http://www.repozytorium.fn.org.pl/?q=pl/node/8797 (dostęp: 28 I 2019).

69 Stato-Citta del Vaticano.

70 Wizyta w Watykanie..., s. 8.

71 W tłumaczeniu na język polski oznacza to bardzo uroczysty.

72 Notatka o wizycie przewodniczącego Rady Państwa PRL Wojciecha Jaruzelskiego w Watykanie (13 I 1987), AMSZ, PRL-Watykan, 1987, 32/90, wiązka I, D IV Wat. 0-2-1-87, s. 1.

73 PKF 4/87, Znad Tybru, http://www.repozytorium.fn.org.pl/?q=pl/node/8797 (dostęp: 28 I 2019).

74 Notatka o wizycie przewodniczącego Rady Państwa PRL Wojciecha Jaruzelskiego w Watykanie (13 I 1987), AMSZ, PRL-Watykan, 1987, 32/90, wiązka I, D IV Wat. 0-22-1-87, s. 2. 
się w pół godziny. Była to najistotniejsza część całej wizyty nie tylko w Watykanie, ale w ogóle podróży na Półwysep Apeniński ${ }^{75}$. Należy zdać sobie sprawę z jeszcze jednego, bardzo istotnego faktu, który wydaje się naturalny, lecz w tym wypadku ma niepoślednie znaczenie. Otóż obydwaj rozmówcy byli Polakami i do rozmowy ze sobą nie potrzebowali tłumacza, co tylko podkreślało wagę rozmowy trwającej niemalże pięć kwadransów.

Dopiero po upływie 74 minut drzwi się otworzyły i zaproszono pozostałą część delegacji ${ }^{76}$, a ponadto wymieniono się podarunkami. O tym, jakie kwestie zostały poruszone podczas rozmowy, można się dowiedzieć jedynie z notatki dotyczącej wizyty przewodniczącego Rady Państwa w Watykanie sporządzonej w Ministerstwie Spraw Zagranicznych ${ }^{77}$.

$\mathrm{Na}$ wstępnie gen. Jaruzelski podkreślił znaczenie swej obecności w Pałacu Apostolskim i możliwość rozmowy z Janem Pawłem II, dziękując za pomoc w realizacji wizyty, w szczególności jeśli chodzi o zaproszenie od premiera Włoch. Polski przywódca twierdził, że rosła wiarygodność władzy PRL w oczach społeczeństwa. Następnie skupił się na gospodarce kraju, wskazując, że kryzys jest nadal widoczny, lecz u podstaw zachodzą już procesy wskazujące na uzdrawianie życia gospodarczego. Wskazane zostało dążenie do poprawnych relacji Polski ze Stanami Zjednoczonymi oraz państwami kapitalistycznymi. Na tej płaszczyźnie pojawił się problem z tworzeniem się coraz silniejszej osi Paryż-Bonn. Nie zabrakło charakterystyki Polski w odniesieniu do Rady Wzajemnej Pomocy Gospodarczej oraz współpracy ze Związkiem Radzieckim. W rozmowie przewinął się również wątek militaryzacji kosmosu, do którego polskie władze były bardzo krytycznie nastawione. Stąd też uznanie dla prac Papieskiej Akademii Nauk, która także miała negatywne stanowisko w tej sprawie. Generał zauważył jednak, że w tym elemencie brakowało jednoznacznego słowa ze strony polskiego Kościoła ${ }^{78}$.

Kiedy rozmowa zeszła na płaszczyznę relacji państwo-Kościół, polski przywódca stwierdził, że stosunki te powinny opierać się na triadzie: ideologicznego i filozoficznego sporu, politycznego wspólistnienia oraz społecznego współdziałania. Dlatego też dużym kłopotem dla władz była postawa większości polskiej hierarchii kościelnej, która nawoływała do absencji w wyborach oraz nie wzięła udziału w obchodach 40 rocznicy Polski Ludowej. Ponadto, jak wspomniał Jaruzelski, tacy „wojujący księża”, jak Henryk Jankowski, tylko utrudniali dialog.

Niezwykle ważnym punktem poruszonym przez obydwie strony była kwestia pielgrzymki Jana Pawła II do Polski. Miało to wielkie znaczenie, ponieważ bezpośrednia rozmowa zdecydowała o zapaleniu „zielonego światła” na przyjazd papieża do ojczyzny jeszcze w tym samym roku. Ojciec Święty odniósł się do wątku niemieckiego,

Wizyta w Watykanie..., s. 12.

Ibidem, s. 14.

77 Notatka o wizycie przewodniczącego Rady Państwa PRL Wojciecha Jaruzelskiego w Watykanie (13 I 1987), AMSZ, PRL-Watykan, 1987, 32/90, wiązka I, D IV Wat. 0-22-1-87, s. 1-13.

78 Ibidem, s. 2-6. 
przypominając, że po roku 1970, czyli podpisaniu układu PRL-RFN, papież Paweł VI ostatecznie uznał przynależność Ziem Odzyskanych ${ }^{79}$. Następca św. Piotra wskazał, że był sam bardzo mocno krytykowany w RFN za swoje wizyty apostolskie we Wrocławiu i na Górze św. Anny, a także liczył się z kolejną krytyką, mającą spaść na niego, kiedy w ramach kolejnej pielgrzymki planował udać się do Szczecina.

Jan Paweł nie zaakceptował postulatu gen. Jaruzelskiego, aby podczas pielgrzymki wspomniał o wspólnej ofierze żołnierzy polskich i radzieckich wyzwalających te ziemie. Ojciec Święty stanowczo zaznaczył, że ta kwestia była poruszana także podczas przygotowań wcześniejszej jego wizyty, lecz nie była realna, gdyż niełatwo można by oddzielić ją od wielu politycznych spekulacji. Trudno dziwić się takiemu argumentowaniu przez następcę św. Piotra.

W toku rozmowy podjęta została przez Jana Pawła II sprawa stosunków dyplomatycznych między Polską a Stolicą Apostolską. Papież zauważył, że jest to pewien trwający proces, który przebiega pomyślnie, do czego przyczyniło się pozytywne stanowisko Episkopatu Polski. Dla Ojca Świętego istniały pewne przeszkody, bez usunięcia których nie byłoby można sfinalizować procesu normalizacji. Taką stanowiła kwestia statusu prawnego Kościoła w Polsce. Na te słowa zareagował Jaruzelski, zauważając pewne problemy, a ponadto wykazując wielkie znaczenie z możliwości nawiązania stosunków dyplomatycznych.

Po rozmowie i przywitaniu z pozostałymi członkami delegacji polskiej zrobiono wspólne zdjęcie oraz wystosowano oświadczenia gospodarza do mediów. Tutaj Jan Paweł II użył sformułowania o „niewątpliwie historycznej wizycie”, które to słowa w ciągu kilku godzin obiegły cały świat, kształtując poglądy na znaczenie tego spotkania ${ }^{80}$.

Na zakończenie wizyty nastąpiło serdeczne pożegnanie między gospodarzem a głównym gościem w Pałacu Apostolskim. Kolejnym punktem była rozmowa gen. Wojciecha Jaruzelskiego z kard. Agostino Casarolim ${ }^{81}$, która trwała 35 minut. Po spotkaniu z sekretarzem stanu delegacja polska zwiedziła Watykan, a na zakończenie przewodniczący Rady Państwa zamienił jeszcze kilka słów z kard. Andrzejem Deskurem. Ważnym punktem były ustalenia dokonane między Marianem Orzechowskim a Achillem Silvestrinim, stanowiące, że ten drugi przybędzie z wizytą do Polski w kwietniu-maju 1987 r. ${ }^{82}$ Dokładnie o 14.32 kolumna samochodów wiozących polskich gości opuściła terytorium Watykanu.

Zamykając wątek przebiegu wizyty, należy zaznaczyć jeszcze jeden znamienny fakt związany z oświadczeniem wydanym przez Biuro Prasowe Stolicy Apostolskiej, które ukazało się w zupełnie innym stylu niż dotychczasowe komunikaty z wizyt

\section{Ibidem, s. 8-9.}

80 Wizyta watykanie..., s. 12.

81 Kard. Agostino Casaroli (1914-1998), sekretarz stanu Stolicy Apostolskiej w latach 1979-1990. Wybitny watykański dyplomata okresu zimnej wojny. Określany mianem architekta watykańskiej polityki wschodniej, czyli koncepcji relacji w stosunku do państw bloku socjalistycznego z ZSRR na czele.

82 Notatka o wizycie przewodniczącego Rady Państwa PRL Wojciecha Jaruzelskiego w Watykanie (13 I 1987), AMSZ, PRL-Watykan, 1987, 32/90, wiązka I, D IV Wat. 0-22-1-87, s. 11. 
zagranicznych delegacji. Zazwyczaj były one bardzo lakoniczne, składające się z jednego, maksymalnie dwóch suchych zdań, w których pisano: „Ojciec Święty przyjął dziś.... W tym wypadku dyrektor Biura Prasowego Joaquin Navarro-Valls ogłosit:

zapowiedziana audiencja Ojca Świętego dla generała Wojciecha Jaruzelskiego, przewodniczącego Rady Państwa PRL, odbyła się w prywatnej bibliotece papieża i trwała ponad 70 minut. Rozmowa była poważna, otwarta, pogłębiona i pozwoliła na analizę problemów społeczeństwa polskiego, stosunków między Kościołem a rządem w Polsce i kwestii dotyczących pokoju międzynarodowego ${ }^{83}$.

Ostatnim punktem wizyty polskich władz na Półwyspie Apenińskim była obecność 14 stycznia 1987 r. na cmentarzu polskich żołnierzy poległych w bitwie pod Monte Cassino. Tutaj gen. Jaruzelski razem z premierem Craxim złożyli wieńce, oddając hołd poległym. Następnie delegacja polska udała się na rzymskie lotnisko, skąd samolotem powróciła do Warszawy.

Po powrocie do Polski delegacji rządowej, zgodnie z protokołem dyplomatycznym, abp Achille Silvestrini przesłał 19 stycznia 1987 r. na ręce przewodniczącego Rady Państwa podziękowania za złożoną wizytę. Prócz kurtuazyjnych podziękowań znalazły się w tym krótkim tekście również słowa odwołujące się do spotkania z gen. Jaruzelskim nie tylko autora dokumentu, lecz także abp. Francesco Colasuonno, jak również ks. Audrysa Backisa ${ }^{84}$ i ks. prał. Janusza Bolonka ${ }^{85}$. Wszyscy wymienieni byli uczestnikami prac prowadzonych przez Radę ds. Publicznych Kościoła oraz rząd PRL. Z takiej dość lakonicznej i kurtuazyjnej informacji można wywnioskować, że owa wizyta była ważnym elementem także dla kręgów watykańskich, nie zaś wyłącznie dla samego papieża Jana Pawła II.

\section{Ocena spotkania w Watykanie gen. Jaruzelskiego i Ojca Świętego w notatce ministra Kuberskiego}

Bardzo ważnym dokumentem podsumowującym styczniową wizytę gen. Jaruzelskiego w Watykanie była notatka informacyjna sporządzona w Rzymie przez Jerzego Kuberskiego 5 lutego 1987 r. Jak stwierdzono w tytule, autor opierał się na ocenach i komentarzach funkcjonujących w Kurii Rzymskiej ${ }^{86}$. Warto jednak szerzej wytłumaczyć, co rozumiano pod określeniem owych kręgów kurialnych. Powoływano się głównie do Sekretariatu Stanu, Rady ds. Publicznych Kościoła i Prefektury Domu Papieskiego.

\footnotetext{
Wizyta w Watykanie..., s. 16.
}

84 Zastępca Sekretarza Rady ds. Publicznych Kościoła.

85 Podziękowania abpa A. Silvestriniego z okazji wizyty przewodniczącego Rady Państwa tow. W. Jaruzelskiego, AAN, Zespół do spraw Kościoła Rzymskokatolickiego, Wizyta tow. Wojciecha Jaruzelskiego w Watykanie 13 I 1987. Przygotowania, przebieg, komentarze. 1986-1987, sygn. 126/52, k. 37.

86 Informacja dot. watykańskich ocen wizyty gen. Jaruzelskiego, AMSZ, Wizyta Przewodniczącego Rady Państwa gen. W. Jaruzelskiego w Watykanie, 1987, 33/90, wiązka VI, D IV Wat. 22-4-87, s. 1. 
Według sporządzonego dokumentu opinie krążące za Spiżową Bramą o wizycie polskiej delegacji, szczególnie bezpośredniego spotkania Wojciecha Jaruzelskiego z Janem Pawłem II, były więcej niż bardzo dobre. Nadal funkcjonował pewien „duch” odwołujący się do słów wypowiedzianych przez Ojca Świętego tuż po rozmowie na osobności z przewodniczącym Rady Państwa podczas briefingu prasowego. Wydarzenie to zostało uznane za światowe, a jego charakter zdecydowanie przekraczał aspekt stosunków państwo-Kościół i PRL-Stolica Apostolska ${ }^{87}$. Najważniejsze było jednak coś innego. Jak zaznaczył Kuberski, wstępna ocena kręgów watykańskich odwoływała się do rozmowy między przywódcami PRL a Kościoła katolickiego przede wszystkim w kontekście „nowego jakościowego kroku” na odcinku normalizacji stosunków pomiędzy Polską a Watykanem, a także w obliczu spraw polskich, jak sytuacja wewnętrzna kraju i pozycja na arenie międzynarodowej ${ }^{88}$.

Sekretariat Stanu uważał, że mimo dość poważnych problemów w relacji państwoKościół i wielu nieudolnych podejmowanych w tym aspekcie działań, pojawienie się rozmów na najwyższym szczeblu pozwalało przypuszczać, że w najbliższym czasie powyższe kłopoty zostaną zlikwidowane. Niezwykle interesująco rysowała się wypowiedź papieża, który według Kuberskiego miał wskazać, że Polska w jego koncepcji miałaby odgrywać bardzo ważną rolę w watykańskiej polityce wschodniej. Przez to pojawiłaby się nowa rola dla ojczyzny Jana Pawła II, która stałaby się wiodącym państwem w obozie socjalistycznym w realizowaniu celów polityki zagranicznej Kościoła katolickiego ${ }^{89}$.

Następnie Kuberski określił, co według opinii funkcjonujących w kurii rzymskiej zostało omówione podczas bezpośredniej rozmowy między przewodniczącym Rady Państwa a Ojcem Świętym. Wskazano trzy podstawowe obszary: problemy pokoju na świecie, włączając w to kwestie rozbrojenia; sytuację wewnętrzną Polski na tle międzynarodowym; problemy z zakresu stosunków państwo-Kościół oraz PRL-Stolica Apostolska. Twierdzono, że papież zapewnił generała o pomocy ze strony dyplomacji watykańskiej na rzecz ułatwienia Polsce odbudowania stosunków z krajami zachodnimi. Ponadto Jan Paweł II miał wyrazić pogląd na temat szczególnego znaczenia Polski w stosunkach międzynarodowych, w których ojczyzna papieża mogłaby odegrać bardzo ważną rolę w zbliżaniu się między Wschodem a Zachodem ${ }^{90}$. Gdy przyjrzeć się wcześniejszemu opisowi wizyty delegacji polskiej w Watykanie, to faktycznie przejawiał się tam aspekt światowego pokoju.

Drugi zakres rozmów został zogniskowany wokół problemów wewnętrznych Polski. Tutaj papież odwoływał się do kwestii związków zawodowych i wprowadzenia pluralizmu z tym związanego. Podkreślony został dialog społeczny jako bardzo ważny element tonowania złych nastrojów w społeczeństwie. Jednakże, według opinii kręgów

\footnotetext{
Ibidem, s. 1.

Ibidem, s. 2.

Ibidem, s. 1.

Ibidem, s. 1-2.
} 
watykańskich, gen. Jaruzelski bardzo nieprzychylnie tłumaczył papieżowi charakter działalności „Solidarności”, która miała wyrządzać wiele szkód państwu polskiemu" ${ }^{91}$.

W kwestii stosunków państwo-Kościół obaj rozmówcy wypowiedzieli się za sfinalizowaniem prac nad statutem prawnym Kościoła katolickiego w Polsce. Podniesiony przez przewodniczącego Rady Państwa problem pełnej normalizacji stosunków na linii Warszawa-Watykan papież uzależnił od pozytywnego rozwiązania tej sprawy oraz pozostałych zagadnień stawianych od lat przez Stolicę Apostolską, jak i Kościół w kraju. Odnosząc się do kleru uprawiającego „politykę z ambon”, gen. Jaruzelski chciał pokazać papieżowi, że Kościół w Polsce również powinien wiele zmienić, aby strona rządowa mogła zacząć przychylniej patrzeć na stawiane postulaty. W odpowiedzi na to Jan Paweł II stwierdził, że nie jest to przejaw działalności antysocjalistycznej, lecz wynika on po postu $\mathrm{z}$ braku pluralizmu $\mathrm{w} \mathrm{kraju}^{92}$. Widać $\mathrm{z}$ tego, że papież twardo rozmawiał z polskim przywódcą, jasno zarzucając łamanie standardów demokratycznych, w które nierozerwalnie wpisuje się przytoczona wcześniej płaszczyzna.

Co ciekawe, włoskie kręgi polityczne i dziennikarskie twierdziły, że polska delegacja była dość chłodno przyjęta za Spiżową Bramą, dlatego też tak mocno starano się podkreślać słowa papieża opisujące wydarzenie to jako „historyczną wizytę"93. Działania te podejmowały zarówno strona polska, jak i Kuria Rzymska. Mimo wielu trudności bezsprzeczne było to, że obydwie strony w konsekwencji widziały konieczność normalizacji stosunków, lecz każda z nich miała w tym swój inny cel i warunki, które trzeba było zrealizować w drodze prowadzącej do niego.

Ogólnie rzecz biorąc, wszelkie komunikaty wystosowane po spotkaniu Wojciecha Jaruzelskiego z Janem Pawłem II były dość lakoniczne, lecz pozytywne. W kraju percepcja owej wizyty była zdecydowanie dobra. Wręcz starano się ją ukazać jako znaczący sukces władz PRL ${ }^{94}$. Co ciekawe, również wśród części duchowieństwa takie głosy były zauważalne, łącznie z tym, że działania rządzących nie tylko dawały pewien postęp w kwestii traktowania Kościoła w Polsce, lecz także dążyły one do wyjścia PRL z izolacji międzynarodowej, która na szeroką skalę zapanowała po 13 grudnia 1981 r. Duchowni zwracali też uwagę, że klimat wytworzony po rozmowach styczniowych w Watykanie mógł być dobrym wstępem do pełnej normalizacji stosunków dyplomatycznych ${ }^{95}$.

\footnotetext{
91 Ibidem, s. 2-3.

Ibidem, s. 3-4.

Ibidem, s. 4.

J. Moskwa, Prorok i polityk, Warszawa 2003, s. 84.

P. Kowal, op. cit., s. 98.
} 


\section{Zakończenie}

Początek roku 1987 był bardzo intensywny dla wzajemnych relacji między PRL a Stolicą Apostolską, a także wypracowywania modus vivendi między państwem a Kościołem. Wizyta delegacji polskiej na czele z gen. Wojciechem Jaruzelskim w Watykanie w styczniu 1987 r. miała charakter przełomowy. Po pierwsze, z uwagi na fakt, że do stycznia 1987 r. nie doszło do żadnego oficjalnego spotkania na terytorium Watykanu między papieżem Janem Pawłem II a przywódcą państwa polskiego ${ }^{96}$. Po drugie, przyglądając się usilnym próbom doprowadzenia do wizyty, podejmowanym ze strony władz w Warszawie, należy podkreślić sukces owych długich i żmudnych działań oraz rokowań. Polegał on nie tylko na poprawieniu relacji z Kościołem, lecz także na pierwszy rzut oka niepozorne spotkanie gen. Jaruzelskiego z Janem Pawłem II ukazało, że walka Warszawy o wydostanie się z izolacji międzynarodowej ${ }^{97}$ po wprowadzeniu stanu wojennego była głównym celem polskich elit oraz dużym problemem na arenie międzynarodowej. Dopiero wizyta w Watykanie, która ze względów formalnych musiała się odbyć na zaproszenie premiera Włoch, spowodowała, że nastąpiło lekkie ocieplenie wizerunku Polski w dyplomacji państw zachodnich. Wreszcie spotkanie przewodniczącego Rady Państwa z Ojcem Świętym było niezwykle znaczące w całym procesie normalizacji stosunków między Polską a Stolicą Apostolską.

Kwestia wyjścia z niebytu na arenie międzynarodowej, w jaki wpadła Polska po 13 grudnia 1981 r., jest bardzo złożona. Andrzej Paczkowski wskazywał, że wznowienie regularnych kontaktów z państwami zachodnimi nastąpiło już pod koniec 1984 r., kiedy doszło w Warszawie do wizyt przedstawicieli Grecji, Finlandii czy Włoch"98. Zatem do wizyty gen. Jaruzelskiego w Watykanie były jeszcze ponad dwa lata. Z artykułu wynika, że dla polskich władz Watykan był kluczowy, aby wydostać PRL z izolacji. Ponadto, mimo wspomnianej przez Paczkowskiego wizyty ministra spraw zagranicznych Włoch Andreottiego, Rzym nie kwapił się do zaproszenia najwyższej polskiej delegacji na Półwysep Apeniński. Szczególnie że zdawano sobie sprawę z tego, że Warszawa mocno zabiegała o możliwość oficjalnego spotkania za Spiżową Bramą z Janem Pawłem II. To pokazuje, że izolacja Polski na arenie międzynarodowej, głównie z państwami Zachodu, trwała, mimo pewnych oznak odprężenia. Dlatego też nadal szukano jakiegoś impulsu mogącego przerodzić się w propagandę sukcesu, a klucz do niej widziano w normalizacji stosunków dyplomatycznych ze Stolicą Apostolską. Ponadto skoro zawodziła sytuacja polityczna i gospodarcza w kraju, myślano o czymś, co

96 Edward Gierek w 1977 r. odbył oficjalną wizytę w Watykanie, podczas której spotkał się z papieżem Pawłem VI. Był on pierwszym przywódcą komunistycznego państwa goszczącym na terytorium Stolicy Apostolskiej.

97 W kontekście państw poza blokiem socjalistycznym.

98 A. Paczkowski, Dyplomacja polska czasów kryzysu (1980-1989), [w:] Historia dyplomacji polskiej..., s. 856 . 
da sygnał społeczeństwu, ukazując, że władza ma wszystko pod kontrolą. Dlatego też zdecydowano się na unormowanie relacji z Kościołem, który w Polsce był od zawsze wielką siłą.

Nie ulega wątpliwości, że gdyby wizyta gen. Jaruzelskiego za Spiżową Bramą nie doszła do skutku, zarówno dalsze rokowania z Watykanem, jak i możliwości przybycia papieża do Polski w ramach III wizyty apostolskiej stanęłyby pod dużym znakiem zapytania. To właśnie bezpośrednia rozmowa gen. Jaruzelskiego z Janem Pawłem II skruszyła pewne lody, występujące na wielu frontach. Oczywiście sytuacja nie zmieniła się w sposób diametralny (co w dyplomacji nie jest zaskoczeniem), lecz wyraźnie daje się zaobserwować przychylniejsze nastawienie ekipy rządzącej w Polsce do Kościoła zarówno w kraju, jak i samej Stolicy Apostolskiej. Nie można przy tym zapominać, że taka gorliwa chęć normalizacji stosunków ze strony władz polskich wynikała z bardzo usilnej chęci wydostania się z izolacji międzynarodowej. Próby te były często nieudolne, a rozmowy niejednokrotnie obnażały słabość i kondycję państwa, które w owym czasie były naprawdę na niskim poziomie.

Ocena wizyty powinna jawić się zatem jako połowiczny sukces polskich władz. Co prawda minister Kuberski pisał, że wszystko miało wymiar niewątpliwie pozytywny, a ponadto w zbliżonej barwie wizyta jawiła się Kurii Rzymskiej, to nie osiągnięto sukcesu w postaci normalizacji stosunków. Z perspektywy gen. Wojciecha Jaruzelskiego oraz papieża Jana Pawła II można stwierdzić, że wizyta była przełomem, dla którego sukcesem było samo spotkanie dwóch przywódców wywodzących się z kraju nad Wisłą. Jednakże drugi cel, czyli normalizacja stosunków dyplomatycznych między Warszawą a Watykanem nadal stanowiła odległy i trudny proces.

Niewątpliwie dalsze rozmowy, rokowania i przebieg procesu normalizacji stosunków dyplomatycznych między PRL a Stolicą Apostolską wymaga kolejnych badań, nad którymi trwają prace autora, czego rezultatem, w przyszłości, będą kolejne publikacje poświęcone tej tematyce.

\section{Bibliografia (Bibliography)}

\section{Źródła archiwalne}

Archiwum Akt Nowych w Warszawie [AAN]

Zespół do spraw Kościoła Rzymskokatolickiego, sygn. 126/52.

Zespół do spraw Kościoła Rzymskokatolickiego, sygn. 126/53.

Archiwum Ministerstwa Spraw Zagranicznych w Warszawie [AMSZ]

PRL-Watykan, 1987, 32/90, wiązka I.

Wizyta Przewodniczącego Rady Państwa gen. W. Jaruzelskiego w Watykanie, 1987, 33/90, wiązka VI. 


\section{Źródła drukowane}

Morawski D., Korespondencja z Rzymu, „Kultura” 1987, nr 3(474), s. 77-79.

Orszulik A., Czas przetomu. Notatki ks. Alojzego Orszulika z rozmów z wtadzami PRL w latach 1981-1989, Warszawa-Ząbki 2006.

\section{Opracowania}

Górska M., Kuligowski J., Kazimierz Barcikowski (1927-2007), drn. ekon.,polityk, wicepremier, dziatacz polityczny i spótdzielczy, „Rocznik Mińsko-Mazowiecki” 2007, nr 15, s. 203-206.

Kowal P., Sprawa wznowienia stosunków dyplomatycznych ze Stolica Apostolska w latach 1986-1989, „Polski Przegląd Dyplomatyczny” 2009, nr 2(48), s. 81-124.

Kumor B., Historia Kościota, t. VIII (Czasy wspótczesne 1914-1992), Lublin 2001.

Materski W., Bilans okresu, [w:] Historia dyplomacji polskiej, t. VI (1944/1945-1989), red. W. Materski, W. Michowicz, Warszawa 2010, s. 930-939.

Moskwa J., Droga Karola Wojtyty, t. II (Zwiastun wyzwolenia 1978-1989), Warszawa 2011.

Moskwa J., Prorok i polityk, Warszawa 2003.

Orszulik A., Droga do petnej normalizacji stosunków między państwem a kościotem oraz między PRL a Stolica Apostolską, „Politeja. Pismo Wydziału Studiów Międzynarodowych i Politologicznych Uniwersytetu Jagiellońskiego” 2014, t. XXIX, s. 331-343

Paczkowski A., Dyplomacja polska czasów kryzysu (1980-1989), [w:] Historia dyplomacji polskiej, t. VI (1944/1945-1989), red. W. Materski, W. Michowicz, Warszawa 2010, s. 821-863.

Weigel G., Świadek nadziei. Biografia papieża Jana Pawta II, Kraków 2005.

Wizyta w Watykanie. 13 stycznia 1987 roku, red. W. Machowski, Warszawa 1987.

Zieliński Z., Dyplomacja polska wobec Watykanu w latach 1945-1989, [w:] Historia dyplomacji polskiej, t. VI (1944/1945-1989), red. W Materski, W. Michowicz, Warszawa 2010, s. 894-929.

\section{Netografia}

https://episkopat.pl/zmarl-bp-alojzy-orszulik-pierwszy-biskup-lowicki/ (dostęp: 26 VI 2019). https://katalog.bip.ipn.gov.pl/informacje/485 (dostęp: 26 VI 2019).

PKF 4/87, Znad Tybru, http://www.repozytorium.fn.org.pl/?q=pl/node/8797 (dostęp: 28 I 2019).

\section{Notka o autorze:}

mgr Michał Owczarek - doktorant w Szkole Doktorskiej Nauk Humanistycznych na Wydziale Filozoficzno-Historycznym Uniwersytetu Łódzkiego.

Zainteresowania badawcze: historia Polski i powszechna w drugiej połowie XX w. i XXI w., historia dyplomacji, Polska Rzeczpospolita Ludowa, polska polityka zagraniczna, stosunki dyplomatyczne PRL-Stolica Apostolska, relacje państwo-Kościół, polityka Stolicy Apostolskiej.

ఐ michal.owczarek@filhist.uni.lodz.pl 